\title{
Biomarkers in cervical cancer screening
}

\author{
Nicolas Wentzensen and Magnus von Knebel Doeberitz* \\ Department of Applied Tumor Biology, Institute of Pathology, University of Heidelberg, and Scientific Cooperation \\ Unit “Cancer Early Detection”, German Cancer Research Center, Im Neuenheimer Feld 220/221, 69120 \\ Heidelberg, Germany
}

\begin{abstract}
In industrialized countries, population wide cytological screening programs using the Pap test have led to a substantial reduction of the incidence of cervical cancer. Despite this evident success, screening programs that rely on Pap-stained cytological samples have several limitations. First, a number of equivocal or mildly abnormal test results require costly work up by either repeated retesting or direct colposcopy and biopsy, since a certain percentage of high grade lesions that require immediate treatment hide among these unclear test results. This work up of mildly abnormal or equivocal cytological tests consumes a large amount of the overall costs spent for cervical cancer screening. Improved triage of these samples might substantially reduce the costs. Cervical cancer is induced by persistent infections with oncogenic human papilloma viruses (HPV). While HPV infection is an indispensable factor, it is not sufficient to cause cancer. The majority of acute HPV infections induce low grade precursor lesions that are cleared spontaneously after several months in more than $90 \%$ of cases, and less than $10 \%$ eventually progress to high grade lesions or invasive cancer. Progression is characterized by the deregulated expression of the viral oncogenes E6 and E7 in infected basal and parabasal cells. Novel biomarkers that allow monitoring these essential molecular events in histological or cytological specimens are likely to improve the detection of lesions that have a high risk of progression in both primary screening and triage settings. In this review, we will discuss potential biomarkers for cervical cancer screening with a focus on the level of clinical evidence that supports their application as novel markers in refined cervical cancer screening programs.
\end{abstract}

Keywords: Cervical cancer, screening, biomarker, HGCIN, HPV, p16 $6^{\mathrm{INK} 4 \mathrm{a}}$

\section{Introduction}

Cervical cancer is a worldwide medical problem with a very disproportionate global distribution. A high incidence is seen in low resource countries, especially in Africa, Latin America, parts of Asia and in some eastern European countries with incidences up to $100 / 100.000$ [91]. In contrast, in industrialized countries, the incidence may be as low as 10/100.000 women [110]. The substantially lower incidence in industrialized countries has been attributed to screening programs that were introduced in these countries over the last 50 years [59], and cervical cancer screening became the paradigm of effective cancer prevention by early detection of preneoplastic lesions. To achieve the low cancer incidence rates by appropriate screening,

*Corresponding author. Tel.: +496221 562877; Fax: +496221 565981; E-mail: knebel@med.uni-heidelberg.de. substantial proportions of the healthcare budgets are used in industrialized countries. The safety of current screening programs is bought dearly by frequent retesting and laborious workup of inconclusive test results. Thus, most of the money spent in this cancer prevention program is due to assay-inherent limitations to identify patients who require further medical intervention. It is assumed that many cancer cases still occurring despite regular screening programs are rather related to failure to participate in screening as opposed to cases missed by screening itself [30]. The improvement of current screening methods therefore has two major goals: First, to offer feasible and affordable screening for the countries that still carry the largest burden of disease, and second to improve the efficiency of current screening programs, to make them more cost-effective by improving the detection of relevant disease and reducing the demand for expensive workup of unclear test results, and to increase the screening coverage of the population. In addition, the recent introduction of pre- 
ventive HPV vaccines may have substantial influence on disease prevalence and will increase the demand of screening assays with better predictive values to detect possible vaccination failures and to pick up precursor lesions that are induced by HPV types not covered by current vaccines [35].

\section{Current cervical cancer screening approaches}

Current cervical cancer screening in industrialized countries is based on the cytology based Pap test. This test has been introduced in the middle of the last century and has not been modified substantially since then.

The major problem of Pap cytology screening is lack of reproducibility of the test results [81]. Many classification systems for cervical cytology have been proposed over the years in different health systems, including the classical Papanicolaou terminology, the $\mathrm{Mu}-$ nich classifications that are closely related to the Papanicolaou system (primarily used in Germany), and the histology oriented WHO classification (frequently used in the UK). The most widely used system is the two-tiered Bethesda classification in that abnormal cells are classified as low grade or high grade squamous intraepithelial lesions (LSIL, HSIL) [97].

LSIL mainly represents morphological correlates of active HPV replication (e.g. koilocytes), whereas HSIL is characterized by morphological alterations indicative of transformation, primarily increasing nuclear alterations. A substantial number of atypical specimens can not be attributed to either one of these categories and are referred to as atypical squamous cells of undetermined significance (ASC-US) or atypical squamous cells can not exclude HSIL (ASC-H) that require further evaluation. Due to the many influencing parameters such as different cytology classifications and different guidelines for the management of abnormal cytology, data about the efficacy of Pap based screening are not easily comparable between different health care systems. Accordingly, the sensitivity of Pap testing for the detection of CIN2 or higher varied between $34 \%$ and $94 \%$ as summarized recently by Wright [126]. In contrast, the specificity of Pap testing is consistently high in the majority of the studies.

In order to compensate the low sensitivity of Pap cytology, the test is frequently repeated.

The main problem of Pap cytology is the large proportion of inconclusive or mildly abnormal test results that may mask a low number of high grade precancerous cases. In the ALTS trial, a two year cumulative diagnosis of CIN3 was found in 8-9\% of the ASC-US cases and in about $15 \%$ of the LSIL cases.

In order to avoid missing these cases, a lot of effort is necessary to work up borderline test results. Several large studies analyzing the management of ASCUS and LSIL have been performed and were reviewed in a recent meta-analysis [3]. Based on these studies, three management strategies are currently performed: Repeat cytology, direct colposcopy and HPV triage of ASC-US. Currently, HPV testing has not been recommended for LSIL, since the vast majority of these lesions are HPV positive. However, recent studies suggest that a risk stratification by HPV single typing might improve HPV based triage both for ASCUS and LSIL [22].

In the British HART study, primary HPV screening was evaluated and found to be a promising alternative to primary screening using cytology [25]. HPV positive cases could be followed up with cytology, however, depending of the population and age of screening, a large number of HPV-infected women that do not have disease or cervical lesions would still require further more detailed work up under these circumstances. So far, other promising biomarkers have not been assessed in sufficiently large primary screening studies.

In the vast majority of developing countries no organized cervical cancer screening programs exist. Opportunistic screening is rarely offered, because there is limited access to infrastructure that allows performing appropriate cytology. In these countries, the detection of cervical cancer and precancer is mainly based on direct visual inspection. One advantage of the visual screening approach is the direct possibility of treating suspect lesions in the same session [26]. However, it is difficult to detect small ectocervical and endocervical lesions under visual inspection; depending on the screening intervals, lesions might be overseen and develop to invasive cancer. On the other side, many changes observed in VIA are rather unspecific and might lead to substantial overtreatment of women without need for it. This in turn triggers an increased risk of premature birth, delivery complications due to stenosis of the uterine canal after invasive procedures in the cervical region, and increased susceptibility towards transmission of other STDs, especially HIV [37].

\section{Potential improvement of cervical cancer screening programs by the use of biomarkers}

There are several fields of application for cancer biomarkers, including early detection of cancers, im- 
proved reproducibility of the histopathological diagnoses, surveillance of persons at risk and post therapy monitoring. In cervical cancer screening, biomarkers are needed that allow to identify persons at risk to develop cancer at a time point that still allows for a successful curative intervention before invasive cancer develops. Biomarker test performance is characterized by measures of sensitivity, specificity, positive predictive value (PPV), and negative predictive value (NPV). Naturally, it is desirable to have assays with both high sensitivity and specificity. A lack of sensitivity will result in missing cases that require treatment. A lack of specificity results in the identification of false positive cases that have to be worked up despite being disease free. PPV and NPV are both related to the test performance and the disease prevalence. The lower disease prevalence is, the lower will be the PPV of an assay with given sensitivity and specificity. The PPV indicates the proportion of individuals tested positive that really have the disease. The NPV gives an indication how safe an assay is, i.e. how sure one can be that a negative result indicates that disease is not present. It is estimated that the introduction of prophylactic HPV vaccines will reduce the incidence of cervical cancers and precursors and therefore will reduce the PPV of abnormal smears from currently $50-70 \%$ down to 10 $20 \%$ in regions with high vaccination coverage [35].

Currently, besides primary Pap screening, only HPV testing has been assessed as a primary screening marker in larger population based studies $[25,86]$.

While cytology results can be very clear with direct clinical implications (a negative or a high grade result) even without control biopsy [6] there are diagnostic categories that have no direct clinical implication, but need to be followed up with more complex clinical algorithms . Unlike cytology, a positive HPV test would always require a follow up before a clinical diagnosis can be established. Different work-up strategies have been suggested, including cytology triage, repeat HPV testing or type-specific HPV detection [25,86] (Wright unpublished results).

The workup of the primary test result (i.e. the triage) can be the second field of application for novel biomarkers. Currently, HPV testing is recommended as one option to triage ASC-US cytology [125]. A biomarker used in triage should be specifically associated with disease progression. Recently, some novel biomarkers such as HPV mRNA and p16 ${ }^{\mathrm{INK} 4 \mathrm{a}}$ have been evaluated in initial studies and have shown promising results but are still lacking validation in larger trials and head to head comparison with HPV testing and other markers [24].
In addition to primary and triage screening markers, biomarkers could be used for a risk assessment of detected lesions, to stratify intermediate lesions, to predict progression and to monitor recurrences after treatment. A very interesting field for biomarkers could be the assessment of CIN1 and CIN2 lesions. While CIN1 is usually managed conservatively, CIN2 is frequently treated despite a rather low progression rate. There are ongoing discussions whether to generally treat CIN2 [99,124]. An important field of application for a biomarker could be the discrimination between $\mathrm{CIN} 1+2$ with a high risk of progression from those lesions with a high chance to spontaneously regress. Treatment would then be restricted to the high risk $\mathrm{CIN} 1+2$ group as indicated by the biomarker.

\section{Identification of novel biomarkers for cervical cancer screening}

In the past 20 years, substantial efforts have been undertaken to identify novel biomarkers for more efficient and cost effective cervical cancer screening programs. Most of the work has been done on the role of HPV testing. This aspect is extensively reviewed by Meijer and colleagues in this issue. Apart from that, numerous other markers have been evaluated in cervical cancer precursor lesions. Due to the accessibility of the uterine cervix, most approaches have concentrated on identifying markers directly in tissue samples taken from the uterine cervix.

\section{Biomarkers derived from the analysis of molecular key events of cervical carcinogenesis}

Some promising biomarkers have recently been delineated by studying the major molecular events involved in cervical carcinogenesis. To facilitate the understanding of the basic molecular concepts that lead to the identification of these markers we briefly summarize the most important steps in cervical transformation in the context of biomarker discovery.

The initial event in cervical transformation is an infection with high risk human papilloma viruses (HRHPV). The majority of HR-HPV infections regress spontaneously, only a small proportion persists and induces cervical intraepithelial neoplasias (CIN). The risk of progression to invasive cancer rises with the lesions' grade [80], Fig. 1. 


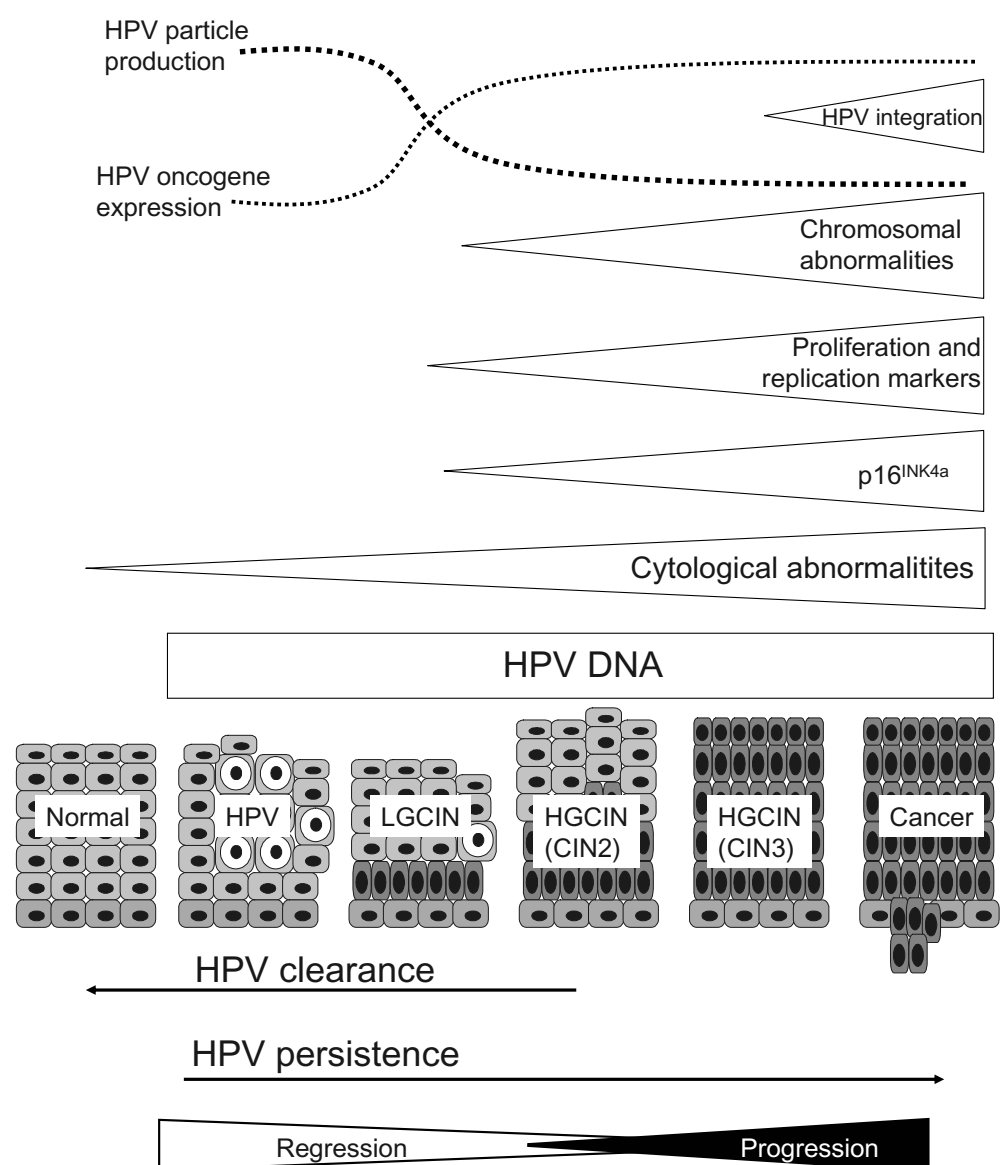

Fig. 1. Progression model of cervical carcinogenesis. During progression from HPV infection to high grade intraepithelial lesions, HPV oncogene expression is substantially increased, while HPV particle production goes down. Deregulated expression of HPV oncogenes induces chromosomal abnormalities, expression of proliferation markers and expression of p16 $6^{\mathrm{NK}} \mathrm{a}$. HPV integration is a rather late event following the chromosomal instability.

The molecular interactions between HPV proteins and host cell proteins and genome homeostasis have been studied intensely over the past 20 years. The early viral genes encode proteins that are involved in the viral life cycle and the late genes encode the viral envelope proteins L1 and L2. Two early genes, E6 and E7 were found to be the most important factors in cellular transformation induced by high risk HPV. The E6 and E7 gene products target a plethora of cellular functions, with the most important interactions being the inactivation of $\mathrm{pRB}$ by $\mathrm{E} 7$ and the degradation of $\mathrm{p} 53$ by E6. Loss of pRB function leads to E2F mediated cell cycle activation that usually would be counteracted by the activation of apoptotic programs in the host cells. However, induction of apoptosis is counteracted by E6 mediated p53 degradation (Fig. 2). The detailed interactions of E6 and E7 with the regulation of apoptosis and cell cycle of the host cell are summarized in [64, 70,133].

During their normal replication oncogenic papillomaviruses avoid pathogenic effects on their host cells in order to multiply themselves largely unnoticed by the infected host. To achieve this, part of the replication strategy relies on the fact that during the normal viral life cycle, E6 and E7 are selectively expressed in the upper epithelial layers to activate the viral replication machinery $[29,102]$. By the restriction of viral replication to terminally differentiated cells that have no proliferation capacity, the virus avoids harmful consequences for its host. The expression of E6 and E7 in replication competent basal cells seems to be tightly suppressed by certain cellular factors that have not been identified yet [132]. The major hallmark of progression from HPV infected tissue to dysplastic lesions is the altered expression pattern of the HPV oncogenes. In high 


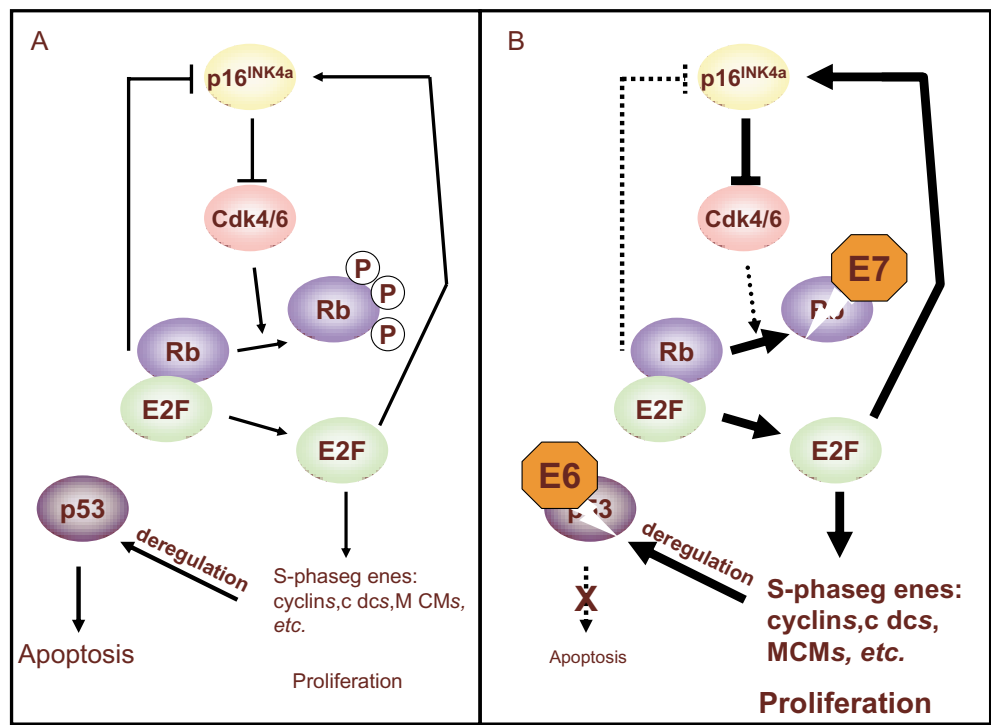

Fig. 2. Schematic diagram of the cellular proteins involved in G1-S phase transition and the interference of HPV oncogenes, adapted from Khleif [54]. A: Strict regulation of E2F in normal cells. Phosphorylation of Rb by Cdk4/6 releases E2F from its binding to Rb and leads to the expression of S-phase genes. Cdk4/6 activity is blocked by p16 ${ }^{\mathrm{NK} 4 \mathrm{a}}$ that is activated by E2F and blocked by Rb/E2F complexes. Deregulated S-phase activation in normal cells would lead to apoptosis. B: Interference of HPV oncoproteins with G1-S-Phase regulation. E7 leads to disruption of $\mathrm{E} 2 \mathrm{~F}-\mathrm{Rb}$ binding. p16 ${ }^{\mathrm{INK} 4 \mathrm{a}}$ is strongly overexpressed due to the loss of Rb/E2F repression and the strong activation by free E2F. However, S-phase genes are continuously activated since the p16 ${ }^{\mathrm{NK}} 4 \mathrm{a}$ mediated repression of Cdk4/6 has no downstream effect on Rb. Apoptosis is abrogated by E6 mediated degradation of p53.

grade CIN lesions, E6 and E7 are strongly expressed in basal epithelial cells and the viral oncogenes interfere substantially with cell cycle control of these replication competent host cells [108]. In the cells uncontrolled proliferation, deregulated cell cycle control, and hence chromosomal instability occurs that results in multiple numeric and structural chromosomal aberrations [27, 28].

In the course of repair processes in chromosomally instable cells, HPV genomes may become integrated into the host cell chromosomes [116,117]. While only a small part of the CIN lesions displays integrated viral genomes, a high percentage of cervical cancers harbors integrated HPV DNA [46,58], suggesting that viral integration is not the cause but rather a consequence of increasing chromosomal instability of HPV transformed cells. During the viral integration process, E2 is usually disrupted and the E6 and E7 genes are conserved. As a result, E6 and E7 expression may be further enhanced [50,51]. Oncogene expression is driven by the viral promoter and can be modulated by surrounding cellular components like cellular promoters, enhancers and repressors or by epigenetic modifications [107]. Recently, it was demonstrated that the E2 binding sites in HPV are differentially methylated indicating that functional inactivation of $\mathrm{E} 2$ might be either related to integration or to methylation of the E2 binding site [7]. The most important cellular and viral changes in the course from HPV infection to invasive cancer are schematically summarized in Fig. 1.

\subsection{Surrogate biomarkers of deregulated $H P V$ oncogene expression}

\subsection{1. $p 16^{\mathrm{INK} 4 \mathrm{a}}$}

The overexpression of the cyclin dependent kinase inhibitor $\mathrm{p} 16^{\mathrm{INK} 4 \mathrm{a}}$ is a direct consequence of deregulated HPV oncogene expression [54]. Usually, binding of $\mathrm{pRB}$ to E2F blocks E2F driven cell cycle activation. In replicating cells, E2F is regulated by phosphorylation of $\mathrm{RB}$. $\mathrm{Rb}$ phosphorylation is normally mediated by cyclin dependent kinases (CDK4, CDK6) that are controlled by several kinase inhibitors (INKs). Aberrant expression of E7 in basal cells disrupts binding of $\mathrm{pRB}$ to E2F that is counteracted by massive expression of p16 ${ }^{\text {INK4a }}$, an important CDK inhibitor (Fig. 2). Since E7-dependent E2F release is not mediated by phosphorylation of $\mathrm{pRb}$, the counter-regulatory $\mathrm{p} 16^{\mathrm{INK} 4 \mathrm{a}}$ expression has no effect on the activated cell cycle [89].

Under physiological conditions $\mathrm{p} 16^{\mathrm{INK} 4 \mathrm{a}}$ is expressed when cells undergo a genomic stress situation such as substantial shortening of telomeres in ageing 


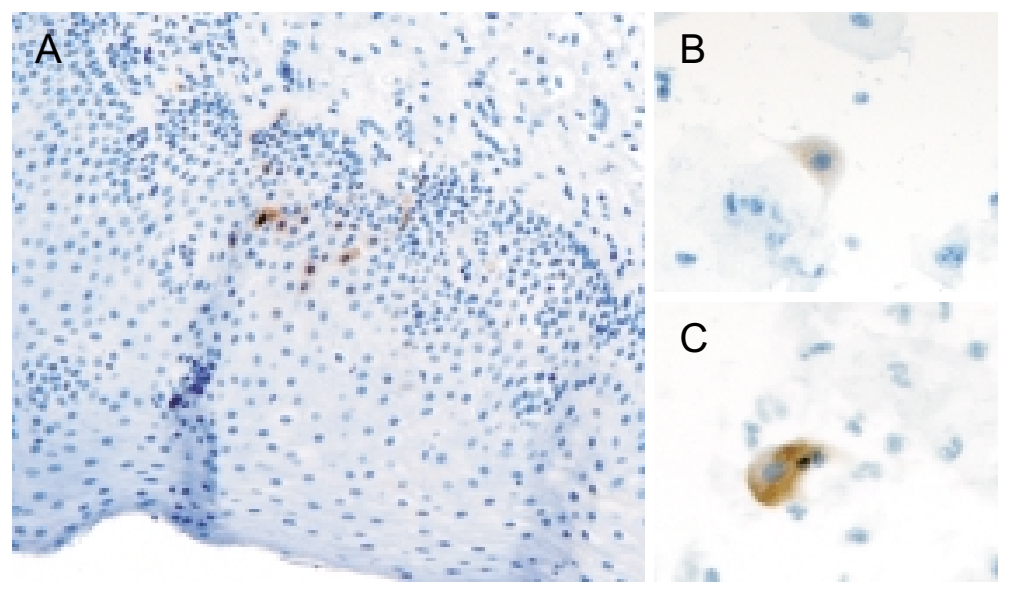

Fig. 3. $\mathrm{p} 16^{\mathrm{INK} 4 \mathrm{a}}$ staining of HPV negative specimens. A: Cervical epithelium with single p16 $6^{\mathrm{NK} 4 \mathrm{a}}$ positive metaplastic cells. B+C: $16^{\mathrm{INK} 4 a}$ positive metaplastic cell in cytology.

tissues [5]. Expression of p16 ${ }^{\text {INK4a }}$ in these cells induces immediate irreversible cell cycle arrest and may finally lead to apoptosis. Thus, independent from HPV, expression of $\mathrm{p} 16^{\mathrm{INK} 4 \mathrm{a}}$ is sometimes observed in single cells that undergo modifications of their normal differentiation program due to aging or genomic stress. Particularly in metaplastic or atrophic epithelial changes in older women, $\mathrm{p} 16^{\mathrm{INK} 4 \mathrm{a}}$ positive cells in the differentiated intermediate or superficial parts of the epithelium may be found that are not considered to be related to HPV oncogene expression (Figs $3 \mathrm{~A}-\mathrm{C}$ ). Nondysplastic epithelia infected with LR- or HR-HPV do not diffusely stain for p16 ${ }^{\text {INK4a }}$ (Fig. 4A+B).

In sharp contrast to this expression pattern of p16 ${ }^{\text {INK4a }}$ in resting cells with aberrant differentiation, the pathological expression in HPV transformed cells is indicated by a very strong diffuse staining pattern in the replicating cells of the basal and parabasal cell layer (Fig. 4C-F). Basically all cervical carcinomas, CIN3 lesions, as well as the majority of CIN2 lesions were found to be diffusely positive in immunohistochemistry (IHC) (Fig. 4C-F). In contrast, only a subset of the CIN1 lesions is p16 ${ }^{\mathrm{INK} 4 \mathrm{a}}$ positive [56,57]. p16 ${ }^{\text {INK4a }}$ IHC improved the reproducibility of histological assessment of CIN lesions in comparison to the conventional H\&E staining [56]. Recent studies have shown that $\mathrm{p} 16^{\mathrm{INK} 4 \mathrm{a}}$ positive low grade lesions have a higher risk of progression than $\mathrm{p} 16^{\mathrm{INK} 4 \mathrm{a}}$ negative lesions $[76,109,111]$, suggesting that $\mathrm{p} 16^{\mathrm{INK} 4 \mathrm{a}}$ could be used as a marker to discriminate lesions with a higher progression risk from those that most likely regress spontaneously. Based on the successful application of p16 ${ }^{\text {INK4a }}$ in IHC, a cytological assay was developed to investigate the $\mathrm{p} 16^{\mathrm{INK} 4 \mathrm{a}}$ expression in exfoliated cells [104]. Several studies have shown that $\mathrm{p} 16^{\text {INK4a }}$ cytology can detect underlying HGCIN with high sensitivity $[40,77,78,128]$. Some authors have counted p16 ${ }^{\text {INK4a }}$ positive cells and have applied cut off levels for the detection of a relevant number of p16 ${ }^{\text {INK4a }}$ positive cells to detect high grade cervical lesions [87, 88 ]. In order to improve the specificity of $\mathrm{p} 16^{\mathrm{INK} 4 \mathrm{a}}$ cytology, a nuclear score was defined that facilitates the assessment of $\mathrm{p} 16^{\mathrm{INK} 4 \mathrm{a}}$ positive cells [114]. Using this score, specificity for the detection of relevant lesions was superior to counting $\mathrm{p} 16^{\mathrm{INK} 4 \mathrm{a}}$ positive cells, while sensitivity was not affected. In a direct comparison with Pap cytology, p16 ${ }^{\text {INK4a }}$ cytology identified $98 \%$ of the HSIL cases, while only $1 \%$ of the normal cases and $10 \%$ of the LSIL cases showed abnormal p16 ${ }^{\text {INK4a }}$ positive cells (Fig. 4G-I).

Based on these results, p16 ${ }^{\mathrm{INK} 4 \mathrm{a}}$ immunocytology might be used to highlight potentially abnormal cells in a background of normal, reactive or other non malignant cells (locator function). Positive cells can then in a second step be score according to morphological criteria (Interpreter function). p16 $6^{\mathrm{INK} 4 \mathrm{a}}$ immunostaining has been used to triage ASCUS and LSIL cases for high grade CIN [20]. In an independent ASC-US/ LSIL triage study, p16 ${ }^{\mathrm{INK} 4 \mathrm{a}}$ cytology applying the above described scoring of nuclear abnormalities had $95 \%$ sensitivity and $84 \%$ specificity in ASC-US and $100 \%$ sensitivity and $82 \%$ specificity in LSIL for the detection of biopsy proven HGCIN (Wentzensen in press). Since p16 ${ }^{\text {INK4a }}$ can be performed from the initial cytology specimen, this application could be a new option for the regular follow up of unclear cytology results. The promising results of this triage study and the high potential for automation of $\mathrm{p} 16^{\mathrm{INK} 4 \mathrm{a}}$ cytology warrant 


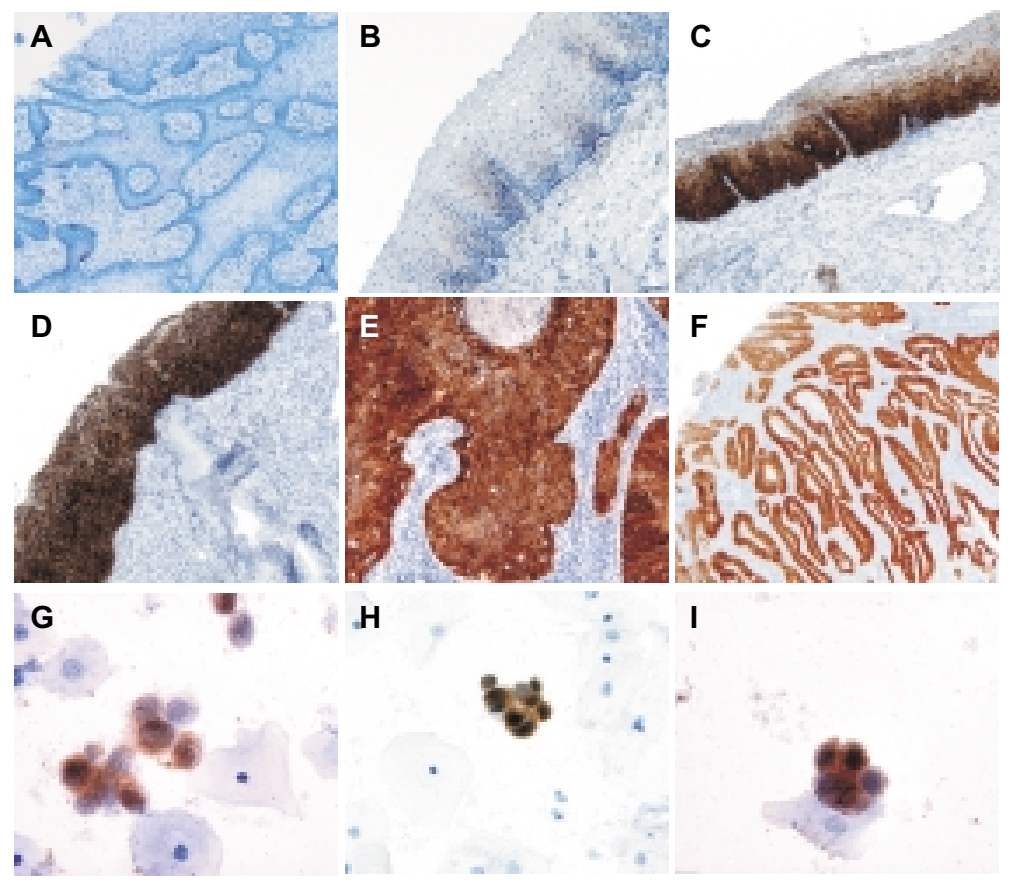

Fig. 4. p16 $6^{\mathrm{INK} 4 \mathrm{a}}$ staining of HPV positive specimens. A: Low risk HPV positive condyloma, no p16 $6^{\mathrm{NK} 4 \mathrm{a}}$ staining. B: High risk HPV positive cervical specimen, no p16 $6^{\mathrm{INK} 4 \mathrm{a}}$ staining C: CIN2 lesion, diffuse p16 $6^{\mathrm{INK} 4 \mathrm{a}}$ staining D: CIN3 lesion, diffuse p16 $6^{\mathrm{INK} 4 a}$ staining E: Cervical squamous cell carcinoma, diffuse $16^{\mathrm{INK} 4 \mathrm{a}}$ staining F: Cervical adenocarcinoma, diffuse p16 $6^{\mathrm{NK} 4 a}$ staining G-I: Cytological specimens with p16 ${ }^{\mathrm{INK} 4 \mathrm{a}}$ positive abnormal cervical cells displaying nuclear abnormalities (H: Seroa Cytoscreen liquid based cytology, G+I: Cytyc Thinprep liquid based cytology).

the evaluation of $\mathrm{p} 16^{\mathrm{INK} 4 \mathrm{a}}$ cytology as a primary cytology screening test along with automated imaging techniques.

A further simplified application of biomarkers in cervical cancer screening is the direct detection of the markers by biochemical techniques in cervical samples. Recently, a biochemical test has been developed that allows to measure $\mathrm{p} 16^{\text {INK4a }}$ levels in solubilized samples obtained from cervical smears. The advantage of this approach is a dichotomous result that is not dependent on the observers' education and experience. Protein based assays are robust and allow for rapid $\mathrm{p} 16^{\mathrm{INK} 4 \mathrm{a}}$ detection procedures that would make a $16^{\text {INK4a }}$ based point of care test possible. An initial study has shown good sensitivity of the assay to detect high grade cervical dysplasia in a disease enriched population [115]. The ELISA based detection of $\mathrm{p} 16^{\mathrm{INK} 4 \mathrm{a}}$ in cervical samples could serve as a quick point of care test in various settings of cervical cancer screening. In countries with cytology screening, it might back up or complement current procedures. In developing countries with no access to screening infrastructure, it could be implemented in visual screening to discriminate lesions with deregulated HPV oncogene expression from non-specific changes that do not require treatment.

\subsection{Markers of chromosomal instability}

\subsubsection{DNA aneuploidy}

Duensing et al. [27,28] have shown that disturbances of the mitotic spindle apparatus are induced early by deregulated expression of HPV oncogenes resulting in non-diploid nuclei (aneuploidy). Consequently, aneuploidy is characteristic for HPV transformed lesions even at precancerous stages $[8,9,67]$. Different techniques exist to measure the DNA content of single cervical cells: Bollmann et al. [8,9] have measured the DNA content of single cells in cytology specimens directly on glass slides using laser scanning microscopy. Melsheimer et al. [67] applied a protocol using minced fresh frozen biopsy specimens followed by flow cytometry DNA content analysis. The studies have shown an association between aneuploidy and increasing dysplasia. Melsheimer and colleagues showed that aneuploidy precedes HPV integration in advanced dysplastic lesions further supporting the notion that integration of viral genomes is the consequence but not the cause of chromosomal instability and transformation [67]. 


\subsubsection{HPV integration}

It is believed that HPV DNA is integrated by chance during the cellular repair processes of double strand breaks. As such, HPV integration is an indicator of severe ongoing chromosomal instability and an advanced stage of the transformation process [117]. Several methods exist to detect the integration of HPV DNA into the host genome. A simple approach is the real time PCR-based quantification of the E2 and E6/E7 gene ratio [82]. E2 is frequently lost upon HPV integration and the theoretical ratio of $1: 1$ between the two genes is expected to be shifted towards E6/E7. However, in many high grade lesions and less advanced cancers, many episomal and few integrated genome copies are found concomitantly, rendering the direct quantification very difficult. Direct proofs of HPV integration are more laborious, since HPV genomes are integrated at random positions in the genome and thus lack a specific sequence that can be amplified. Integration detection assays use primers binding to specific restriction enzyme sites for amplification [103], or perform digestion of the target DNA and ligate either adaptors [63] or use self ligation [52] to construct templates that allow for amplification and sequencing of the unknown cellular sequence.

The RNA-based amplification of viral-cellular fusion transcripts specific for HPV integration [58] is less laborious than the DNA based integration detection assays but requires fresh frozen material with proper RNA quality. Several clinical applications of HPV integration detection exist: HPV integration detection is highly specific for advanced lesions, but lacks sensitivity since all studies measuring HPV integration directly have not shown more than $80-90 \%$ integration positive cervical cancers. HPV integration points to advanced lesions with a very high progression potential, i.e. lesions that would clearly require treatment. Although some clustering of HPV integration events has been found most probably related to fragile sites in that region, every HPV integration event is unique with respect to the exact integration site [116,131]. It was shown that all cells are clonally related with respect to the HPV integration site in cervical cancers and in high grade precancer lesions $[106,131]$ allowing to use HPV integration as a very specific tumor marker in post-treatment surveillance.

\subsection{Markers of proliferation and host cell genome replication}

\subsection{1. ki67}

The increased proliferation of cervical epithelial cells induced by deregulated HPV oncogene expres- sion is reflected by the activation of proliferation markers such as ki67 (MIB-1). This protein is strongly expressed in CIN lesions, but can also be found expressed in normal basal cells that retain proliferation capacity $[38,83]$. By analyzing the association between lesion grade and the epithelial location of ki67 positive cell clusters, Kruse et al. have demonstrated that ki67 cell clusters are a good criterion to discriminate low grade CIN lesions from normal and reactive epithelia [60].

\subsection{2. $M Y C$}

The cellular oncogene MYC is frequently found amplified and overexpressed in cervical cancer. Several studies have shown MYC activation at premalignant stages, indicating that MYC detection might be used to assess dysplastic lesions. Golijow et al. have performed PCR based detection of MYC amplification on histological and cytological specimens and found MYC levels increasing with lesion grade at premalignant stages [39]. In a consecutive study, Abba et al. [1] showed a tight correlation between MYC expression and HPV16 infection at pre-invasive stages, indicating different oncogenic properties of different HR-HPV types.

\subsubsection{Cyclins}

Cyclins are a large family of regulatory proteins with central functions in the coordination of the cell cycle. The expression of several cyclins has been analyzed in cervical cancer and precancer. Cyclin D1 was found to be overexpressed in low grade lesions induced by LR-HPV, while it was absent in HR-HPV induced lesions [98]. Other cyclins such as A, B, and E were found to be overexpressed in premalignant cervical lesions [31,53]. Weaver et al. have analyzed the expression of Cyclin E in liquid based cytology specimens and found a strong association of Cyclin E with HPV induced cellular abnormalities [113].

\subsubsection{Telomerase}

Telomerase expression is important to counteract the loss of sequences located at the outermost chromosome endings that naturally occurs during every cell division. To prevent loss of relevant chromosomal sequences, the telomerase complex adds short repetetive DNA stretches to the chromosome endings. Telomerase consists of a protein subunit and an RNA subunit that is template for the repetitive sequences. The gene encoding the RNA subunit, TERC, is located on chromosome $3 q$, a region that is frequently amplified in cervical cancer and precancer. Since telomerase is 
necessary to maintain telomere length in proliferating cells, it is found overexpressed in many human cancers. Several groups have used a functional telomerase assay to evaluate telomerase activity on cervical smears. Increased telomerase activity was mainly found in advanced dysplasias with varying sensitivity for the detection of HGCIN [4,49].

\subsubsection{Replication complex proteins}

MCM5 and CDC6 belong to the DNA pre-replication complex that is usually expressed in replicating, but not in quiescent cells. The replication licensing complex is disassembled during replication to prevent immediate reinitiating of the cell cycle. In dysplastic cervical cells, a continuous activation of the replication complex is found. Williams et al. have analyzed of a modified Pap staining protocol including immunocytochemical detection of the replication complex proteins CDC6 and MCM5. The authors describe good sensitivity and specificity of the assay for the detection of SIL in a series of 92 cervical smears [120]. These results were confirmed by Murphy et al. in an independent study [71]. In frame of the HPV-PathogenISS study, Branca and colleagues found that topoisomerase II alpha (TOP2A) expression was correlated with the progression from CIN2 to CIN3 [15]. The detection of two proliferation associated proteins, MCM2 and TOP2A, has been recently made commercially available. An initial study [92] showed $100 \%$ positivity of the marker combination in high grade SIL cytology specimens without staining of normal specimens, while $50 \%$ of LSIL and $20 \%$ of ASC-US cases were found to be positive.

\subsection{Markers of cellular stress and invasion}

HSPs are chaperones protecting cellular functions in response to various cellular stresses that were found to be overexpressed in a number of cancers. In cervical precancer, overexpression of HSP40, HSP60 and HSP70 were associated with increasing lesion grade [21]. The Carbonic anhydrase 9 is a transmembrane protein induced by lowered oxygen tension. The CA9/MN antigen has been identified as a marker for all grades of CIN [85]. Liao et al. have analyzed CA9 expression on cervical smears and found expression in all grades of dysplasia as well as some slides exhibiting only atypical cells. For the cytological diagnosis of atypical glandular cells of unknown significance (AGUS), CA9/MN expression pointed to relevant lesions [62]. Laminin 5 is part of cell adhesion complexes and is an important constituent of the extracellular matrix. It was found to be an invasion marker in various epithelial tumors, including cervical cancer [96]. Laminin 5 seems to be a late marker of the cervical transformation process indicating the first steps of invasion [79].

\subsection{Epigenetic markers, factors enhancing viral oncogene activity}

Methylation of $\mathrm{CpG}$ islands is an epigenetic modifier of gene expression. In many cancers, tumor suppressor genes were found to be inactivated by methylation. Likewise, many studies have looked at gene methylation alterations in cervical cancer and precancer. RASSF1 methylation was found in cervical cancer and seems to complement the frequent $\mathrm{LOH}$ and $\mathrm{CGH}$ losses detected at the $3 \mathrm{p} 21$ region [129]. TSLC1 has been described as a cellular tumor suppressor gene involved in cervical cancer development. TSLC1 was found inactivated by methylation in a subset of high grade dysplasias and cervical carcinomas [100]. Recently, methylation studies were performed on cytological and corresponding histological specimens of women with CIN and cervical cancer [33]. Using three target genes, DAPK1, RARB, or TWIST1, the authors found a $60 \%$ sensitivity for the detection of CIN3 with a specificity of $95 \%$.

The brn-3a transcription factor is a potent activator of HR-HPV gene expression. A massive overexpression was found in women with CIN3 as compared to women without cervical lesion [74]. Interestingly, the massive overxpression was not only observed in the lesions, but also in the non-diseased tissue surrounding the CIN3 lesions suggesting that high brn-3a expression might be an important risk factor for the development of HRHPV induced high grade lesions [72]. The group has analyzed the use of brn-3a mRNA quantification from cytology specimens and found a correlation between high brn-3a levels and increased risk of progression to high grade lesions in different populations $[73,94,95]$.

\section{Identification of biomarkers for cervical cancer screening by profiling approaches}

\subsection{Chromosomal abnormalities}

Comparative genomic hybridization (CGH) assays can measure altered distributions of genomic DNA on a genome wide basis. The resolution of the CGH mapping has substantially increased during the last years 
from bacterial artificial chromosomes to array CGH using short DNA clones. In various independent studies, more gains than losses have been observed in $\mathrm{CGH}$ studies of cervical cancer [48,127]. Chromosomal aberrations can be identified already in precancerous lesions [45], the frequency of imbalances was found to increase from $19 \%$ in CIN1 to over $90 \%$ in CIN3 lesions [105,127]. The typical chromosomal losses are $2 \mathrm{q}, 3 \mathrm{p}, 4 \mathrm{p}, 4 \mathrm{q}, 5 \mathrm{q}, 6 \mathrm{q}, 11 \mathrm{q}, 13 \mathrm{q}$, and 18q, frequently gained regions are 1q, 3q, 5p, and 8q [41,44,45,55,66, $84,105,127]$.

The most consistently observed alteration seems to be the gain of chromosome $3 \mathrm{q}$, an event that has been associated with the progression from severe dysplasia to invasive cancer $[42,43]$. The TERC gene coding for the RNA subunit of telomerase is located on 3q. The frequent alterations at this locus together with other functional studies on the role of telomerase in cervical carcinogenesis [130] suggest that TERC amplification might be a necessary step for cervical cancer development. Heselmeyer-Haddad et al. [43] have analyzed the use of a $3 q$ specific probe set on Pap stained cervical smears to detect lesions progressing to CIN3. The authors were able to identify CIN1/2 progressing to CIN3 with a $100 \%$ sensitivity, while $70 \%$ of the regressing lesions were negative for $3 q$ gain.

Recently, Huang et al. [47] have found a potentially cervical cancer promoting gene, PRKAA1, located on the frequently amplified short arm of chromosome 5 by detailed analysis of gene copy number of several candidate genes in that region.

In a recent paper, Fitzpatrick and colleagues [34] have performed extensive gene expression analysis based on 3 different microarray platforms to compare expression data with chromosomal imbalances. There was a good correlation between chromosomal gains and alterations of genes located on $3 q$ and $12 q$ as well as loss of $6 \mathrm{p}$ and $4 \mathrm{q}$.

\subsubsection{Alterations of gene expression}

Nees et al. [75] have compared gene expression patterns between tumorigenic and non-tumorigenic HPV16 immortalized human foreskin keratinocytes and identified 49 significantly altered genes, among them the proliferation associated gene $\mathrm{C} 4.8$ that was found to be overexpressed in high grade cervical lesions [121]. Wong et al. [123] have used microarray expression patterns to discriminate normal cervical tissue from cervical cancers. Using specific gene expression signatures, the authors were able to stratify stage Ib and IIb cancers and to predict the patients response to radiotherapy. Chen et al. [23] have determined global expression patterns of 34 cervical tissues derived from different disease stages and identified 35 candidate biomarkers that were validated on tissue microarrays including a number of cell cycle regulatory genes.

Ahn et al. [2] have analyzed gene expression patterns of primary cancer tissue of 11 patients and found 74 differentially regulated genes. Fujimoto et al. [36] have used gene expression patterns to compare morphologically different cervical cancer cell lines derived from one donor. In a recent analysis, Steinau et al. [101] have compared primary cervical tissue with normal exfoliated cells from 7 donors to evaluate the differences between the two tissue sources. About $50 \%$ of the genes present in the primary tissue could also be identified in exfoliated cells indicating that this is only a partial representation probably related to the under-representation of normal basal cells in exfoliated tissue. In addition, the gene expression patterns between 15 CIN3 lesions and 15 normal or CIN1 tissues were compared, 6 commonly altered genes were identified. Santin et al. [90] have performed a microarray analysis comparing gene expression patterns of cervical carcinomas and normal cervical keratinocytes. Among more than 500 differentially regulated genes, the authors identified several biomarkers that have been previously analyzed in functional studies of HPV-induced transformation, including CDKN2A/p16 $16^{\mathrm{INK} 4 \mathrm{a}}$, topoisomerase $2 \mathrm{~A}$, and minichromosome maintenance proteins 2,4 , and 5 .

\subsubsection{Alteration of protein expression, serum based markers}

So far, only few studies exist that have used proteomic tools to identify new cervical cancer biomarkers. Lee et al. [61] have analyzed the proteomic changes induced by transfection of E7 into the HPV negative cell line C33a to identify proteins regulated by E7. Wong et al. [122] have used the SELDI technology to compare protein mass patterns between cervical cancer and non-diseased tissue and achieved a $87 \%$ sensitivity and $100 \%$ specificity for the classification of tissue using seven specific protein mass patterns.

A number of protein biomarkers have been analyzed in serum to detect cervical cancer, among them the SCC antigen [32], IGF2 and VEGF-C [65,68] and CYFRA 21.1 [69]. Recently, the methylation of CDH1 and $\mathrm{CDH} 2$ genes has been analyzed in serum samples [119]. None of these markers has shown a clinical utility superior to the analysis of directly sampled exfoliated cells so far. 
The analysis of humoral immune responses against HPV antigens has not been proven to be a valuable tool for cervical cancer screening [93], however, with the introduction of more powerful techniques covering a wide spectrum of HPV antigens [112], new possible fields of application for HPV serology are conceivable, especially considering the forthcoming vaccination against some HPV types.

\subsection{Markers analyzed in the HPV-Pathogen ISS study}

The HPV-Pathogen ISS study aims at systematically analyzing 13 different biomarkers in defined retrospective, cross-sectional, and prospective cohorts of HIV positive and negative women [12]. The women are followed both with epidemiological surveys and regular colposcopy including sampling for HPV and biomarker analysis. The 13 markers were selected from different sources, mainly including genes known to be involved in the carcinogenesis of other tumor entities, some identified in profiling analysis and some known to be associated with HPV-related transformation. Until now, several markers have been analyzed in retrospective, cross-sectional and prospective analyses, including ERK1 [11], Survivin [19], VEGFC [18], 67kd-laminin receptor [16], nucleosid diphosphate kinase nm23-h1 [13], MMP2 and TIMP-2 [10], E-cadherin [14], and NF-kappa-B [17]. Two very promising marker candidates analyzed in this series are Survivin and VEGF-C. Survivin is involved both in cell cycle and apoptosis regulation [118]. Survivin gene expression is usually repressed by wild type p53. As such, its overexpression indirectly indicates E6 mediated p53 degradation. Survivin was found to be an early marker of cervical carcinogenesis, expression strength increased with lesion grade [19]. VEGF is upregulated by E6 independent from p53. VEGF overexpression was found to be an early marker of CIN and correlated linearly with lesion grade [18].

\section{Summary}

Currently, a number of potential biomarkers for cervical screening are being analyzed. The best data are available for HPV DNA based markers, the comprehensive exploration of HPV DNA in the progression from transient infection to cervical cancer raises the bar for the validation of new potential biomarkers. These analyses, however, have also clearly demonstrated that there is a need for new tools that can discriminate le- sions with high risk of progression from those that will regress spontaneously. Such markers might be viral markers, like HPV mRNA or HR-HPV single typing. The advantage of cellular markers like $\mathrm{p} 16^{\mathrm{INK} 4 \mathrm{a}}$ is the association with the transformation process independent of the underlying HPV type. This allows to analyze only a single marker, while HPV based assays will always need to target several oncogenic types. In histology applications, $\mathrm{p} 16^{\mathrm{INK} 4 \mathrm{a}}$ has shown excellent results in improving the reproducibility of cervical precancer histology diagnoses. Several approaches to identify high grade lesions using p16 ${ }^{\text {INK4a }}$ cytology have been published. It is very likely that a combined protocol using $\mathrm{p} 16^{\mathrm{INK} 4 \mathrm{a}}$ staining as a biomarker and nuclear assessment of $\mathrm{p} 16^{\mathrm{INK} 4 \mathrm{a}}$ positive cells might substantially improve the triage of unclear cytology results. The p16 ${ }^{\mathrm{INK} 4 \mathrm{a}}$ ELISA format may offer a quick and simple assay that can determine the risk of underlying high grade disease independent of the observer's education and a skillful lab environment.

A clear demand in the assessment of novel biomarkers is a standardized approach. Most studies on cervical cancer biomarkers are not comparable and thus do not allow to draw meaningful conclusions at this point. With regard to standardization, the approach of the HPV-PathogenISS study is very helpful and it will be interesting to see more prospective data on different biomarkers. A further step in that direction is the SUCCEED study, a combined epidemiological, pathological, and clinical approach to identify new and validate existing biomarker, conducted by the NCI. The study aims at collecting biological material from more than 1500 women with transient HPV infection, different grades of cervical dysplasia, and cervical cancer and will allow for a thorough comparison of different candidate biomarkers at different steps in the progression to cervical cancer.

Finally, the soon expected introduction of regular vaccination programs against the oncogenic high risk types HPV16 and HPV18 is expected to have an influence on the incidence of HPV infections and HPV associated lesions in the short term and on cervical cancer incidence in the long term. It is assumed that these changes in disease prevalence and a possible shift towards more frequent infections by HPV types not targeted by the vaccine might make cytology based screening more ineffective than it is now and will therefore increase the demand for new biomarkers. 


\section{References}

[1] M.C. Abba, R.M. Laguens, F.N. Dulout and C.D. Golijow, The c-myc activation in cervical carcinomas and HPV 16 infections, Mutat Res 557(2) (2004), 151-158.

[2] W.S. Ahn, S.M. Bae, J.M. Lee, S.E. Namkoong, S.J. Han, Y.L. Cho YL et al., Searching for pathogenic gene functions to cervical cancer, Gynecol Oncol 93(1) (2004), 41-48.

[3] M. Arbyn, F. Buntinx, M. Van Ranst, E. Paraskevaidis, P. Martin-Hirsch and J. Dillner, Virologic versus cytologic triage of women with equivocal Pap smears: a meta-analysis of the accuracy to detect high-grade intraepithelial neoplasia, J Natl Cancer Inst 96(4) (2004), 280-293.

[4] K.A. Ault, H.K. Allen, S.L. Phillips, M.B. Zimmerman and A.J. Klingelhutz, Telomerase activity as a potential diagnostic marker for triage of abnormal Pap smears, J Low Genit Tract Dis 9(2) (2005), 93-99.

[5] C.M. Beausejour, A. Krtolica, F. Galimi, M. Narita, S.W. Lowe, P. Yaswen et al., Reversal of human cellular senescence: roles of the p53 and p16 pathways, EMBO J 22(16) (2003), 4212-4222.

[6] L. Berdichevsky, R. Karmin and L. Chuang, Treatment of high-grade squamous intraepithelial lesions: a 2- versus 3step approach, Am J Obstet Gynecol 190(5) (2004), 14241426.

[7] B. Bhattacharjee and S. Sengupta, CpG methylation of HPV $16 \mathrm{LCR}$ at E2 binding site proximal to $\mathrm{P} 97$ is associated with cervical cancer in presence of intact E2. Virology 2006.

[8] R. Bollmann, M. Bollmann, D.E. Henson and M. Bodo, DNA cytometry confirms the utility of the Bethesda system for the classification of Papanicolaou smears, Cancer 93(3) (2001), 222-228.

[9] R. Bollmann, G. Mehes, R. Torka, N. Speich, C. Schmitt and M. Bollmann, Determination of features indicating progression in atypical squamous cells with undetermined significance: human papillomavirus typing and DNA ploidy analysis from liquid-based cytologic samples, Cancer 99(2) (2003), 113-117.

[10] M. Branca, M. Ciotti, C. Giorgi, D. Santini, L. Di Bonito, S. Costa et al., Matrix metalloproteinase-2 (MMP-2) and its tissue inhibitor (TIMP-2) are prognostic factors in cervical cancer, related to invasive disease but not to high-risk human papillomavirus (HPV) or virus persistence after treatment of CIN, Anticancer Res 26(2B) (2006), 1543-1556.

[11] M. Branca, M. Ciotti, D. Santini, L.D. Bonito, A. Benedetto, C. Giorgi et al., Activation of the ERK/MAP kinase pathway in cervical intraepithelial neoplasia is related to grade of the lesion but not to high-risk human papillomavirus, virus clearance, or prognosis in cervical cancer, Am J Clin Pathol 122(6) (2004), 902-911.

[12] M. Branca, S. Costa, L. Mariani, F. Sesti, A. Agarossi, A. di Carlo et al., Assessment of risk factors and human papillomavirus (HPV) related pathogenetic mechanisms of CIN in HIV-positive and HIV-negative women. Study design and baseline data of the HPV-PathogenISS study, Eur J Gynaecol Oncol 25(6) (2004), 689-698.

[13] M. Branca, C. Giorgi, M. Ciotti, D. Santini, L. Di Bonito, S. Costa et al., Down-regulated nucleoside diphosphate (NDP) kinase nm23-h1 expression is unrelated to high-risk human papillomavirus (HPV) but associated with progression of cin and unfavourable prognosis in cervical cancer, J Clin Pathol (2006).

[14] M. Branca, C. Giorgi, M. Ciotti, D. Santini, L. Di Bonito, S. Costa et al., Down-regulation of E-cadherin is closely asso- ciated with progression of cervical intraepithelial neoplasia (CIN), but not with high-risk human papillomavirus (HPV) or disease outcome in cervical cancer, Eur J Gynaecol Oncol 27(3) (2006), 215-223.

[15] M. Branca, C. Giorgi, M. Ciotti, D. Santini, L. Di Bonito, S. Costa et al., Over-Expression of Topoisomerase IIalpha is Related to the Grade of Cervical Intraepithelial Neoplasia (CIN) and High-Risk Human Papillomavirus (HPV), but does not Predict Prognosis in Cervical Cancer or HPV Clearance after Cone Treatment, Int J Gynecol Pathol 25(4) (2006), 383-392.

[16] M. Branca, C. Giorgi, M. Ciotti, D. Santini, L. Di Bonito, S. Costa et al., Relationship of up-regulation of 67-kd laminin receptor to grade of cervical intraepithelial neoplasia and to high-risk HPV types and prognosis in cervical cancer, Acta Cytol 50(1) (2006), 6-15.

[17] M. Branca, C. Giorgi, M. Ciotti, D. Santini, L. Di Bonito, S. Costa et al., Upregulation of nuclear factor-kappaB (NFkappaB) is related to the grade of cervical intraepithelial neoplasia, but is not an independent predictor of high-risk human papillomavirus or disease outcome in cervical cancer, Diagn Cytopathol 34(8) (2006), 555-563.

[18] M. Branca, C. Giorgi, D. Santini, L. Di Bonito, M. Ciotti, A. Benedetto et al., Aberrant expression of VEGF-C is related to grade of cervical intraepithelial neoplasia (CIN) and high risk HPV, but does not predict virus clearance after treatment of CIN or prognosis of cervical cancer, J Clin Pathol 59(1) (2006), 40-47.

[19] M. Branca, C. Giorgi, D. Santini, L. Di Bonito, M. Ciotti, S. Costa et al., Survivin as a marker of cervical intraepithelial neoplasia and high-risk human papillomavirus and a predictor of virus clearance and prognosis in cervical cancer, Am J Clin Pathol 124(1) (2005), 113-121.

[20] F. Carozzi, S. Cecchini, M. Confortini, V. Becattini, M.P. Cariaggi, G. Pontenani et al., Role of P16((INK4a)) expression in identifying CIN2 or more severe lesions among HPVpositive patients referred for colposcopy after abnormal cytology, Cancer (2006).

[21] P.E. Castle, R. Ashfaq, F. Ansari and C.Y. Muller, Immunohistochemical evaluation of heat shock proteins in normal and preinvasive lesions of the cervix, Cancer Lett 229(2) (2005), 245-252.

[22] P.E. Castle, D. Solomon, M. Schiffman and C.M. Wheeler, Human papillomavirus type 16 infections and 2-year absolute risk of cervical precancer in women with equivocal or mild cytologic abnormalities, J Natl Cancer Inst 97(14) (2005), 1066-1071.

[23] Y. Chen, C. Miller, R. Mosher, X. Zhao, J. Deeds, M. Morrissey et al., Identification of cervical cancer markers by $\mathrm{cD}$ NA and tissue microarrays, Cancer Res 63(8) (2003), 19271935.

[24] J. Cuzick, M.H. Mayrand, G. Ronco, P. Snijders and P. Wardle, Chapter 10: New dimensions in cervical cancer screening, Vaccine 24(Suppl 3) (2006), S90-S97.

[25] J. Cuzick, A. Szarewski, H. Cubie, G. Hulman, H. Kitchener, D. Luesley et al., Management of women who test positive for high-risk types of human papillomavirus: the HART study, Lancet 362(9399) (2003), 1871-1876.

[26] L. Denny, L. Kuhn, M. De Souza, A.E. Pollack, W. Dupree and T.C. Wright, Jr., Screen-and-treat approaches for cervical cancer prevention in low-resource settings: a randomized controlled trial, JAMA 294(17) (2005), 2173-2181. 
[27] S. Duensing and K. Munger, Centrosome abnormalities, genomic instability and carcinogenic progression, Biochim Biophys Acta 1471(2) (2001), M81-M88.

[28] S. Duensing and K. Munger, The human papillomavirus type 16 E6 and E7 oncoproteins independently induce numerical and structural chromosome instability, Cancer Res 62(23) (2002), 7075-7082.

[29] M. Durst, D. Glitz, A. Schneider and H. zur Hausen, Human papillomavirus type 16 (HPV 16) gene expression and DNA replication in cervical neoplasia: analysis by in situ hybridization, Virology 189(1) (1992), 132-140.

[30] S. Eaker, H.O. Adami, F. Granath, E. Wilander and P. Sparen, A large population-based randomized controlled trial to increase attendance at screening for cervical cancer, Cancer Epidemiol Biomarkers Prev 13(3) (2004), 346-354.

[31] A.A. El Ghobashy, A.M. Shaaban, J. Herod, J. Innes, W. Prime and C.S. Herrington, Overexpression of cyclins A and $\mathrm{B}$ as markers of neoplastic glandular lesions of the cervix, Gynecol Oncol 92(2) (2004), 628-634.

[32] M.D. Esajas, J.M. Duk, H.W. de Bruijn, J.G. Aalders, P.H. Willemse, W. Sluiter et al., Clinical value of routine serum squamous cell carcinoma antigen in follow-up of patients with early-stage cervical cancer, J Clin Oncol 19(19) (2001), 3960-3966.

[33] Q. Feng, A. Balasubramanian, S.E. Hawes, P. Toure, P.S. Sow, A. Dem et al., Detection of hypermethylated genes in women with and without cervical neoplasia, J Natl Cancer Inst 97(4) (2005), 273-282.

[34] M.A. Fitzpatrick, M.C. Funk, D. Gius, P.C. Huettner, Z. Zhang, M. Bidder et al., Identification of chromosomal alterations important in the development of cervical intraepithelial neoplasia and invasive carcinoma using alignment of DNA microarray data, Gynecol Oncol (2006).

[35] E.L. Franco, J. Cuzick, A. Hildesheim and S. de Sanjose, Chapter 20: Issues in planning cervical cancer screening in the era of HPV vaccination, Vaccine 24(Suppl 3) (2006), S171-S177.

[36] T. Fujimoto, A. Nishikawa, M. Iwasaki, N. Akutagawa, M. Teramoto and R. Kudo, Gene expression profiling in two morphologically different uterine cervical carcinoma cell lines derived from a single donor using a human cancer cDNA array, Gynecol Oncol 93(2) (2004), 446-453.

[37] A. Goel, G. Gandhi, S. Batra, S. Bhambhani, V. Zutshi and P. Sachdeva, Visual inspection of the cervix with acetic acid for cervical intraepithelial lesions, Int J Gynaecol Obstet 88(1) (2005), 25-30.

[38] M.M. Goel, A. Mehrotra, U. Singh, H.P. Gupta and J.S. Misra, MIB-1 and PCNA immunostaining as a diagnostic adjunct to cervical Pap smear, Diagn Cytopathol 33(1) (2005), 15-19.

[39] C.D. Golijow, M.C. Abba, S.A. Mouron, M.A. Gomez and F.N. Dulout, c-myc gene amplification detected in preinvasive intraepithelial cervical lesions, Int J Gynecol Cancer 11(6) (2001), 462-465.

[40] M. Guo, L. Hu, M. Baliga, Z. He and M.D. Hughson, The Predictive Value of p16^(INK4a) and Hybrid Capture 2 Human Papillomavirus Testing for High-Grade Cervical Intraepithelial Neoplasia, Am J Clin Pathol 122(6) (2004), 894-901.

[41] C.P. Harris, X.Y. Lu, G. Narayan, B. Singh, V.V. Murty and P.H. Rao, Comprehensive molecular cytogenetic characterization of cervical cancer cell lines, Genes Chromosomes Cancer 36(3) (2003), 233-241.

[42] K. Heselmeyer, E. Schrock, M.S. du, H. Blegen, K. Shah, R. Steinbeck et al., Gain of chromosome $3 q$ defines the transition from severe dysplasia to invasive carcinoma of the uterine cervix, Proc Natl Acad Sci USA 93(1) (1996), 479-484.

[43] K. Heselmeyer-Haddad, K. Sommerfeld, N.M. White, N. Chaudhri, L.E. Morrison, N. Palanisamy et al., Genomic amplification of the human telomerase gene (TERC) in pap smears predicts the development of cervical cancer, Am J Pathol 166(4) (2005), 1229-1238.

[44] A. Hidalgo, M. Baudis, I. Petersen, H. Arreola, P. Pina, G. Vazquez-Ortiz et al., Microarray comparative genomic hybridization detection of chromosomal imbalances in uterine cervix carcinoma, BMC Cancer 5 (2005), 77.

[45] A. Hidalgo, C. Schewe, S. Petersen, M. Salcedo, P. Gariglio, K. Schluns et al., Human papilloma virus status and chromosomal imbalances in primary cervical carcinomas and tumour cell lines, Eur J Cancer 36(4) (2000), 542-548.

[46] A.H. Hopman, M.A. Kamps, F. Smedts, E.J. Speel, C.S. Herrington and F.C. Ramaekers, HPV in situ hybridization: impact of different protocols on the detection of integrated HPV, Int J Cancer 115(3) (2005), 419-428.

[47] F.Y. Huang, P.M. Chiu, K.F. Tam, Y.K. Kwok, E.T. Lau, M.H. Tang et al., Semi-quantitative fluorescent PCR analysis identifies PRKAA1 on chromosome 5 as a potential candidate cancer gene of cervical cancer, Gynecol Oncol 103(1) (2006), 219-225.

[48] F.Y. Huang, Y.K. Kwok, E.T. Lau, M.H. Tang, T.Y. Ng and H.Y. Ngan, Genetic abnormalities and HPV status in cervical and vulvar squamous cell carcinomas, Cancer Genet Cytogenet 157(1) (2005), 42-48.

[49] E.A. Jarboe, L.C. Thompson, D. Heinz, J.A. McGregor and K.R. Shroyer, Telomerase and human papillomavirus as diagnostic adjuncts for cervical dysplasia and carcinoma, Hum Pathol 35(4) (2004), 396-402.

[50] S. Jeon, B.L. Allen-Hoffmann and P.F. Lambert, Integration of human papillomavirus type 16 into the human genome correlates with a selective growth advantage of cells, $J$ Virol 69(5) (1995), 2989-2997.

[51] S. Jeon and P.F. Lambert, Integration of human papillomavirus type 16 DNA into the human genome leads to increased stability of E6 and E7 mRNAs: implications for cervical carcinogenesis, Proc Natl Acad Sci USA 92(5) (1995), 1654-1658.

[52] M. Kalantari, E. Blennow, B. Hagmar and B. Johansson, Physical state of HPV16 and chromosomal mapping of the integrated form in cervical carcinomas, Diagn Mol Pathol 10(1) (2001), 46-54.

[53] J.T. Keating, A. Cviko, S. Riethdorf, L. Riethdorf, B.J. Quade, D. Sun et al., Ki-67, cyclin E, and p16INK4 are complimentary surrogate biomarkers for human papilloma virusrelated cervical neoplasia, Am J Surg Pathol 25(7) (2001), 884-891.

[54] S.N. Khleif, J. DeGregori, C.L. Yee, G.A. Otterson, F.J. Kaye, J.R. Nevins et al., Inhibition of cyclin D-CDK4/CDK6 activity is associated with an E2F-mediated induction of cyclin kinase inhibitor activity, Proc Natl Acad Sci USA 93(9) (1996), 4350-4354.

[55] M. Kirchhoff, H. Rose, B.L. Petersen, J. Maahr, T. Gerdes, C. Lundsteen et al., Comparative genomic hybridization reveals a recurrent pattern of chromosomal aberrations in severe dysplasia/carcinoma in situ of the cervix and in advancedstage cervical carcinoma, Genes Chromosomes Cancer 24(2) (1999), 144-150.

[56] R. Klaes, A. Benner, T. Friedrich, R. Ridder, S. Herrington, D. Jenkins et al., p16INK4a immunohistochemistry improves interobserver agreement in the diagnosis of cervical 
intraepithelial neoplasia, Am J Surg Pathol 26(11) (2002), 1389-1399.

[57] R. Klaes, T. Friedrich, D. Spitkovsky, R. Ridder, W. Rudy, U. Petry et al., Overexpression of p16(INK4A) as a specific marker for dysplastic and neoplastic epithelial cells of the cervix uteri, Int J Cancer 92(2) (2001), 276-284.

[58] R. Klaes, S.M. Woerner, R. Ridder, N. Wentzensen, M. Duerst, A. Schneider et al., Detection of high-risk cervical intraepithelial neoplasia and cervical cancer by amplification of transcripts derived from integrated papillomavirus oncogenes, Cancer Res 59(24) (1999), 6132-6136.

[59] L.G. Koss, The Papanicolaou test for cervical cancer detection. A triumph and a tragedy, JAMA 261(5) (1989), 737743.

[60] A.J. Kruse, J.P. Baak, T. Helliesen, K.H. Kjellevold, M.G. Bol and E.A. Janssen, Evaluation of MIB-1-positive cell clusters as a diagnostic marker for cervical intraepithelial neoplasia, Am J Surg Pathol 26(11) (2002), 1501-1507.

[61] K.A. Lee, J.W. Kang, J.H. Shim, C.W. Kho, S.G. Park, H.G. Lee et al., Protein profiling and identification of modulators regulated by human papillomavirus $16 \mathrm{E} 7$ oncogene in HaCaT keratinocytes by proteomics, Gynecol Oncol 99(1) (2005), 142-152.

[62] S.Y. Liao and E.J. Stanbridge, Expression of MN/CA9 protein in Papanicolaou smears containing atypical glandular cells of undetermined significance is a diagnostic biomarker of cervical dysplasia and neoplasia, Cancer 88(5) (2000), $1108-1121$.

[63] F. Luft, R. Klaes, M. Nees, M. Durst, V. Heilmann, P. Melsheimer et al., Detection of integrated papillomavirus sequences by ligation-mediated PCR (DIPS-PCR) and molecular characterization in cervical cancer cells, Int J Cancer 92(1) (2001), 9-17.

[64] F. Mantovani and L. Banks, The human papillomavirus E6 protein and its contribution to malignant progression, Oncogene 20(54) (2001), 7874-7887.

[65] S.P. Mathur, R.S. Mathur, E.A. Gray, D. Lane, P.G. Underwood, M. Kohler et al., Serum vascular endothelial growth factor C (VEGF-C) as a specific biomarker for advanced cervical cancer: Relationship to insulin-like growth factor II (IGF-II), IGF binding protein 3 (IGF-BP3) and VEGF-A [corrected], Gynecol Oncol 98(3) (2005), 467-483.

[66] C.P. Matthews, K.A. Shera and J.K. McDougall, Genomic changes and HPV type in cervical carcinoma, Proc Soc Exp Biol Med 223(3) (2000), 316-321.

[67] P. Melsheimer, S. Vinokurova, N. Wentzensen, G. Bastert and M. von Knebel Doeberitz, DNA aneuploidy and integration of human papillomavirus type 16 e6/e7 oncogenes in intraepithelial neoplasia and invasive squamous cell carcinoma of the cervix uteri, Clin Cancer Res 10(9) (2004), 3059-3063.

[68] A. Mitsuhashi, K. Suzuka, K. Yamazawa, H. Matsui, K. Seki and S. Sekiya, Serum vascular endothelial growth factor (VEGF) and VEGF-C levels as tumor markers in patients with cervical carcinoma, Cancer 103(4) (2005), 724-730.

[69] R. Molina, X. Filella, J.M. Auge, E. Bosch, A. Torne, J. Pahisa et al., CYFRA 21.1 in patients with cervical cancer: comparison with SCC and CEA, Anticancer Res 25(3A) (2005), 1765-1771.

[70] K. Munger, J.R. Basile, S. Duensing, A. Eichten, S.L. Gonzalez, M. Grace et al., Biological activities and molecular targets of the human papillomavirus E7 oncoprotein, Oncogene 20(54) (2001), 7888-7898.
[71] N. Murphy, M. Ring, C.C. Heffron, B. King, A.G. Killalea, C. Hughes et al., p16INK4A, CDC6, and MCM5: predictive biomarkers in cervical preinvasive neoplasia and cervical cancer, J Clin Pathol 58(5) (2005), 525-534.

[72] D. Ndisang, V. Budhram-Mahadeo, A. Singer and D.S. Latchman, Widespread elevated expression of the human papilloma virus (HPV)-activating cellular transcription factor Brn-3a in the cervix of women with CIN3 (cervical intraepithelial neoplasia stage 3), Clin Sci (Lond) 98(5) (2000), 601-602.

[73] D. Ndisang, F. Lorenzato, M. Sindos, A. Singer and D.S. Latchman, Detection of cervical abnormalities in a developing country using measurement of Brn-3a in cervical smears, Gynecol Oncol 100(1) (2006), 89-94.

[74] D. Ndisdang, P.J. Morris, C. Chapman, L. Ho, A. Singer and D.S. Latchman, The HPV-activating cellular transcription factor Brn-3a is overexpressed in CIN3 cervical lesions, $J$ Clin Invest 101(8) (1998), 1687-1692.

[75] M. Nees, E. van Wijngaarden, E. Bakos, A. Schneider and M. Durst, Identification of novel molecular markers which correlate with HPV-induced tumor progression, Oncogene 16(19) (1998), 2447-2458.

[76] G. Negri, F. Vittadello, F. Romano, A. Kasal, F. Rivasi, S. Girlando et al., P16(INK4a) expression and progression risk of low-grade intraepithelial neoplasia of the cervix uteri, Virchows Arch (2004).

[77] S. Nieh, S.F. Chen, T.Y. Chu, H.C. Lai and E. Fu, Expression of p16 INK4A in Papanicolaou smears containing atypical squamous cells of undetermined significance from the uterine cervix, Gynecol Oncol 91(1) (2003), 201-208.

[78] S. Nieh, S.F. Chen, T.Y. Chu, H.C. Lai, Y.S. Lin, E. Fu et al., Is p16(INK4A) expression more useful than human papillomavirus test to determine the outcome of atypical squamous cells of undetermined significance-categorized Pap smear? A comparative analysis using abnormal cervical smears with follow-up biopsies, Gynecol Oncol 97(1) (2005), 35-40.

[79] J.C. Noel, S. Fernandez-Aguilar, I. Fayt, F. Buxant, M.H. Ansion, P. Simon et al., Laminin-5 gamma 2 chain expression in cervical intraepithelial neoplasia and invasive cervical carcinoma, Acta Obstet Gynecol Scand 84(11) (2005), 1119-1123.

[80] A.G. Ostor, Natural history of cervical intraepithelial neoplasia: a critical review, Int J Gynecol Pathol 12(2) (1993), 186-192.

[81] J.P. O'Sullivan, R.P. A'Hern, P.A. Chapman, L. Jenkins, R. Smith, A. al Nafussi et al., A case-control study of truepositive versus false-negative cervical smears in women with cervical intraepithelial neoplasia (CIN) III, Cytopathology 9(3) (1998), 155-161.

[82] P. Peitsaro, B. Johansson and S. Syrjanen, Integrated human papillomavirus type 16 is frequently found in cervical cancer precursors as demonstrated by a novel quantitative real-time PCR technique, J Clin Microbiol 40(3) (2002), 886-891.

[83] E.C. Pirog, R.N. Baergen, R.A. Soslow, D. Tam, A.E. DeMattia, Y.T. Chen et al., Diagnostic Accuracy of Cervical Low-Grade Squamous Intraepithelial Lesions Is Improved With MIB-1 Immunostaining, Am J Surg Pathol 26(1) (2002), $70-75$.

[84] P.H. Rao, H. Arias-Pulido, X.Y. Lu, C.P. Harris, H. Vargas, F.F. Zhang et al., Chromosomal amplifications, 3q gain and deletions of $2 \mathrm{q} 33-\mathrm{q} 37$ are the frequent genetic changes in cervical carcinoma, BMC Cancer 4 (2004), 5.

[85] M. Resnick, S. Lester, J.E. Tate, E.E. Sheets, C. Sparks and C.P. Crum, Viral and histopathologic correlates of MN and 
MIB-1 expression in cervical intraepithelial neoplasia, Hum Pathol 27(3) (1996), 234-239.

[86] G. Ronco, N. Segnan, P. Giorgi-Rossi, M. Zappa, G.P. Casadei, F. Carozzi et al., Human papillomavirus testing and liquid-based cytology: results at recruitment from the new technologies for cervical cancer randomized controlled trial, J Natl Cancer Inst 98(11) (2006), 765-774.

[87] S. Sahebali, C.E. Depuydt, G.A. Boulet, M. Arbyn, L.M. Moeneclaey, A.J. Vereecken et al., Immunocytochemistry in liquid-based cervical cytology: Analysis of clinical use following a cross-sectional study, Int J Cancer (2005).

[88] S. Sahebali, C.E. Depuydt, K. Segers, L.M. Moeneclaey, A.J. Vereecken, E. Van Marck et al., P16INK4a as an adjunct marker in liquid-based cervical cytology, Int J Cancer 108(6) (2004), 871-876

[89] T. Sano, T. Oyama, K. Kashiwabara, T. Fukuda and T. Nakajima, Expression status of p16 protein is associated with human papillomavirus oncogenic potential in cervical and genital lesions, Am J Pathol 153(6) (1998), 1741-1748.

[90] A.D. Santin, F. Zhan, E. Bignotti, E.R. Siegel, S. Cane, S. Bellone et al., Gene expression profiles of primary cervical cancers, Virology 331(2) (2005), 269-291.

[91] V. Shanta, S. Krishnamurthi, C.K. Gajalakshmi, R. Swaminathan and K. Ravichandran, Epidemiology of cancer of the cervix: global and national perspective, J Indian Med Assoc 98(2) (2000), 49-52.

[92] K.R. Shroyer, P. Homer, D. Heinz and M. Singh, Validation of a novel immunocytochemical assay for topoisomerase IIalpha and minichromosome maintenance protein 2 expression in cervical cytology, Cancer (2006).

[93] I. Silins, E. Avall-Lundqvist, A. Tadesse, K.U. Jansen, U. Stendahl, P. Lenner et al., Evaluation of antibodies to human papillomavirus as prognostic markers in cervical cancer patients, Gynecol Oncol 85(2) (2002), 333-338.

[94] M. Sindos, D. Ndisang, N. Pisal, C. Chow, A. Deery, A. Singer et al., Detection of cervical neoplasia using measurement of Brn-3a in cervical smears with persistent minor abnormality, Int J Gynecol Cancer 13(4) (2003), 515-517.

[95] M. Sindos, D. Ndisang, N. Pisal, C. Chow, A. Singer and D.S. Latchman, Measurement of Brn-3a levels in Pap smears provides a novel diagnostic marker for the detection of cervical neoplasia, Gynecol Oncol 90(2) (2003), 366-371.

[96] B. Skyldberg, S. Salo, E. Eriksson, U. Aspenblad, B. Moberger, K. Tryggvason et al., Laminin-5 as a marker of invasiveness in cervical lesions, J Natl Cancer Inst 91(21) (1999), 1882-1887.

[97] D. Solomon, D. Davey, R. Kurman, A. Moriarty, D. O'Connor, M. Prey et al., The 2001 Bethesda System: terminology for reporting results of cervical cytology, JAMA 287(16) (2002), 2114-2119.

[98] S.A. Southern and C.S. Herrington, Differential cell cycle regulation by low- and high-risk human papillomaviruses in low-grade squamous intraepithelial lesions of the cervix, Cancer Res 58(14) (1998), 2941-2945.

[99] M. Spitzer, B.S. Apgar and G.L. Brotzman, Management of histologic abnormalities of the cervix, Am Fam Physician 73(1) (2006), 105-112.

[100] R.D. Steenbergen, D. Kramer, B.J. Braakhuis, P.L. Stern, R.H. Verheijen, C.J. Meijer et al., TSLC1 gene silencing in cervical cancer cell lines and cervical neoplasia, $J$ Nat Cancer Inst 96(4) (2004), 294-305.

[101] M. Steinau, D.R. Lee, M.S. Rajeevan, S.D. Vernon, M.T. Ruffin and E.R. Unger, Gene expression profile of cervical tissue compared to exfoliated cells: impact on biomarker discovery, BMC Genomics 6(1) (2005), 64.

[102] M.H. Stoler, C.R. Rhodes, A. Whitbeck, S.M. Wolinsky, L.T. Chow and T.R. Broker, Human papillomavirus type 16 and 18 gene expression in cervical neoplasias, Hum Pathol 23(2) (1992), 117-128

[103] E.C. Thorland, S.L. Myers, D.H. Persing, G. Sarkar, R.M. McGovern, B.S. Gostout et al., Human papillomavirus type 16 integrations in cervical tumors frequently occur in common fragile sites, Cancer Res 60(21) (2000), 5916-5921.

[104] M.J. Trunk, G. Dallenbach-Hellweg, R. Ridder, U. Petry, H. Ikenberg, V. Schneider et al., Morphologic Characteristics of p16 ${ }^{\mathrm{INK} 4 \mathrm{a}}-$ Positive Cells in Cervical Cytology Samples, Acta Cytol 48(6) (2004), 771-782.

[105] K. Umayahara, F. Numa, Y. Suehiro, A. Sakata, S. Nawata, H. Ogata et al., Comparative genomic hybridization detects genetic alterations during early stages of cervical cancer progression, Genes Chromosomes Cancer 33(1) (2002), 98-102.

[106] S. Vinokurova, N. Wentzensen, J. Einenkel, R. Klaes, C. Ziegert, P. Melsheimer et al., Clonal history of papillomavirus-induced dysplasia in the female lower genital tract, J Natl Cancer Inst 97(24) (2005), 1816-1821.

[107] M. von Knebel Doeberitz, T. Bauknecht, D. Bartsch and H. zur Hausen, Influence of chromosomal integration on glucocorticoid-regulated transcription of growth-stimulating papillomavirus genes E6 and E7 in cervical carcinoma cells, Proc Natl Acad Sci USA 88(4) (1991), 1411-1415.

[108] M. von Knebel Doeberitz, New markers for cervical dysplasia to visualise the genomic chaos created by aberrant oncogenic papillomavirus infections, Eur J Cancer 38(17) (2002), 2229-2242.

[109] J.L. Wang, B.Y. Zheng, X.D. Li, T. Angstrom, M.S. Lindstrom and K.L. Wallin, Predictive significance of the alterations of p16INK4A, p14ARF, p53, and proliferating cell nuclear antigen expression in the progression of cervical cancer, Clin Cancer Res 10(7) (2004), 2407-2414.

[110] S.S. Wang, M.E. Sherman, A. Hildesheim, J.V. Lacey, Jr. and S. Devesa, Cervical adenocarcinoma and squamous cell carcinoma incidence trends among white women and black women in the United States for 1976-2000, Cancer 100(5) (2004), 1035-1044.

[111] S.S. Wang, M. Trunk, M. Schiffman, R. Herrero, M.E. Sherman, R.D. Burk et al., Validation of p16INK4a as a marker of oncogenic human papillomavirus infection in cervical biopsies from a population-based cohort in Costa Rica, Cancer Epidemiol Biomarkers Prev 13(8) (2004), 1355-1360.

[112] T. Waterboer, P. Sehr, K.M. Michael, S. Franceschi, J.D. Nieland, T.O. Joos et al., Multiplex human papillomavirus serology based on in situ-purified glutathione s-transferase fusion proteins, Clin Chem 51(10) (2005), 1845-1853.

[113] E.J. Weaver, A.J. Kovatich and M. Bibbo, Cyclin E expression and early cervical neoplasia in ThinPrep specimens. A feasibility study, Acta Cytol 44(3) (2000), 301-304.

[114] N. Wentzensen, C. Bergeron, F. Cas, D. Eschenbach, S. Vinokurova and M. von Knebel Doeberitz, Evaluation of a nuclear score for p16INK4a-stained cervical squamous cells in liquid-based cytology samples, Cancer 105(6) (2005), 461467.

[115] N. Wentzensen, M. Hampl, M. Herkert, A. Reichert, M.J. Trunk, C. Poremba et al., Identification of high-grade cervical dysplasia by the detection of p16(INK4a) in cell lysates obtained from cervical samples, Cancer 107(9) (2006), 23072313. 
[116] N. Wentzensen, R. Ridder, R. Klaes, S. Vinokurova, U. Schaefer and M. von Knebel Doeberitz, Characterization of viral-cellular fusion transcripts in a large series of HPV16 and 18 positive anogenital lesions, Oncogene 21(3) (2002), 419-426.

[117] N. Wentzensen, S. Vinokurova and M. von Knebel Doeberitz, Systematic review of genomic integration sites of human papillomavirus genomes in epithelial dysplasia and invasive cancer of the female lower genital tract, Cancer Res 64(11) (2004), 3878-3884

[118] S.P. Wheatley and I.A. McNeish, Survivin: a protein with dual roles in mitosis and apoptosis, Int Rev Cytol 247 (2005), 35-88.

[119] A. Widschwendter, L. Ivarsson, A. Blassnig, H.M. Muller, H. Fiegl, A. Wiedemair et al., CDH1 and CDH13 methylation in serum is an independent prognostic marker in cervical cancer patients, Int J Cancer 109(2) (2004), 163-166.

[120] G.H. Williams, P. Romanowski, L. Morris, M. Madine, A.D. Mills, K. Stoeber et al., Improved cervical smear assessment using antibodies against proteins that regulate DNA replication, Proc Natl Acad Sci USA 95(25) (1998), 14932-14937.

[121] V. Wollscheid, R. Kuhne-Heid, I. Stein, L. Jansen, S. Kollner, A. Schneider et al., Identification of a new proliferationassociated protein NET-1/C4.8 characteristic for a subset of high-grade cervical intraepithelial neoplasia and cervical carcinomas, Int J Cancer 99(6) (2002), 771-775.

[122] Y.F. Wong, T.H. Cheung, K.W. Lo, V.W. Wang, C.S. Chan, T.B. Ng et al., Protein profiling of cervical cancer by proteinbiochips: proteomic scoring to discriminate cervical cancer from normal cervix, Cancer Lett 211(2) (2004), 227-234.

[123] Y.F. Wong, Z.E. Selvanayagam, N. Wei, J. Porter, R. Vittal, R. Hu et al., Expression genomics of cervical cancer: molecular classification and prediction of radiotherapy response by DNA microarray, Clin Cancer Res 9(15) (2003), 5486-5492.

[124] T.C. Wright, Jr., J.T. Cox, L.S. Massad, J. Carlson, L.B. Twiggs and E.J. Wilkinson, 2001 consensus guidelines for the management of women with cervical intraepithelial neoplasia, Am J Obstet Gynecol 189(1) (2003), 295-304.

[125] T.C. Wright, Jr., J.T. Cox, L.S. Massad, L.B. Twiggs and E.J.
Wilkinson, 2001 Consensus Guidelines for the management of women with cervical cytological abnormalities, JAMA 287(16) (2002), 2120-2129.

[126] T.C. Wright, Jr., M. Schiffman, D. Solomon, J.T. Cox, F. Garcia, S. Goldie et al., Interim guidance for the use of human papillomavirus DNA testing as an adjunct to cervical cytology for screening, Obstet Gynecol 103(2) (2004), 304 309.

[127] Y.C. Yang, W.Y. Shyong, M.S. Chang, Y.J. Chen, C.H. Lin, Z.D. Huang et al., Frequent gain of copy number on the long arm of chromosome 3 in human cervical adenocarcinoma, Cancer Genet Cytogenet 131(1) (2001), 48-53.

[128] T. Yoshida, T. Fukuda, T. Sano, T. Kanuma, N. Owada and T. Nakajima, Usefulness of liquid-based cytology specimens for the immunocytochemical study of p16 expression and human papillomavirus testing: a comparative study using simultaneously sampled histology materials, Cancer 102(2) (2004), 100-108.

[129] M.Y. Yu, J.H. Tong, P.K. Chan, T.L. Lee, M.W. Chan, A.W. Chan et al., Hypermethylation of the tumor suppressor gene RASSFIA and frequent concomitant loss of heterozygosity at 3p21 in cervical cancers, Int J Cancer 105(2) (2003), 204209.

[130] A. Zhang, J. Wang, B. Zheng, X. Fang, T. Angstrom, C. Liu et al., Telomere attrition predominantly occurs in precursor lesions during in vivo carcinogenic process of the uterine cervix, Oncogene 23(44) (2004), 7441-7447.

[131] C. Ziegert, N. Wentzensen, S. Vinokurova, F. Kisseljov, J. Einenkel, M. Hoeckel et al., A comprehensive analysis of HPV integration loci in anogenital lesions combining transcript and genome-based amplification techniques, Oncogene 22(25) (2003), 3977-3984.

[132] H. zur Hausen, Immortalization of human cells and their malignant conversion by high risk human papillomavirus genotypes, Semin Cancer Biol 9(6) (1999), 405-411.

[133] H. zur Hausen, Papillomaviruses and cancer: from basic studies to clinical application, Nat Rev Cancer 2(5) (2002), $342-350$. 


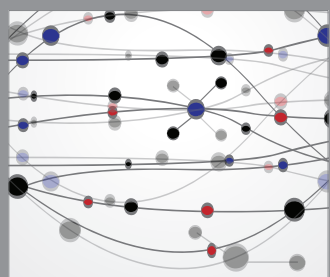

The Scientific World Journal
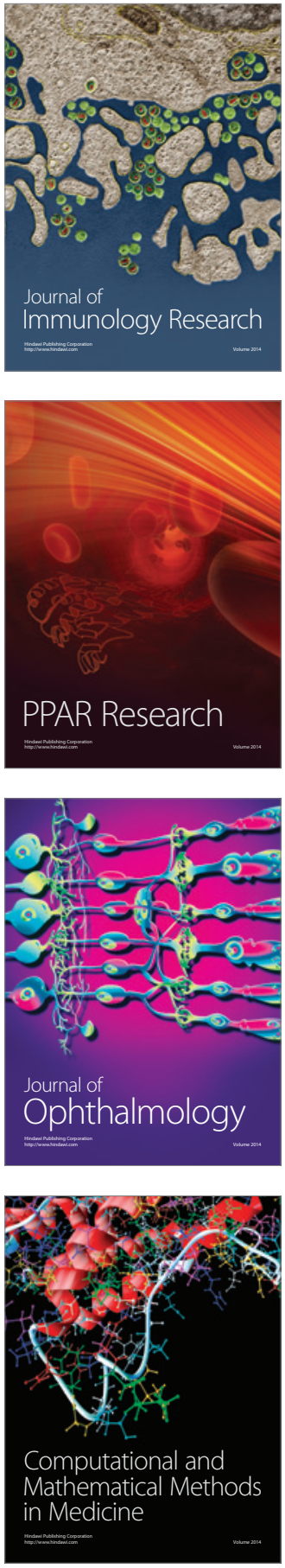

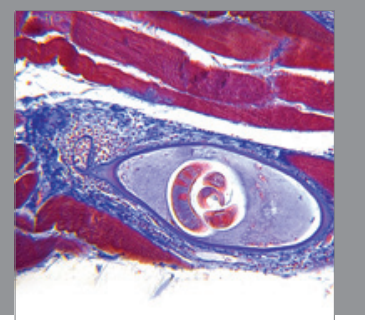

Gastroenterology

Research and Practice
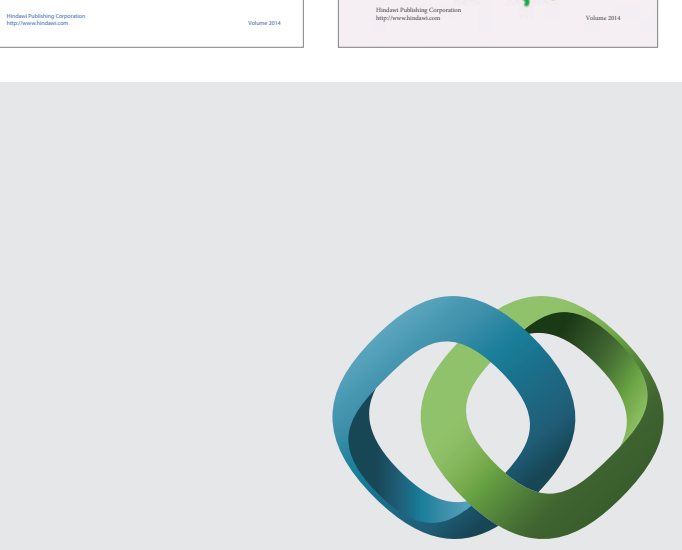

\section{Hindawi}

Submit your manuscripts at

http://www.hindawi.com
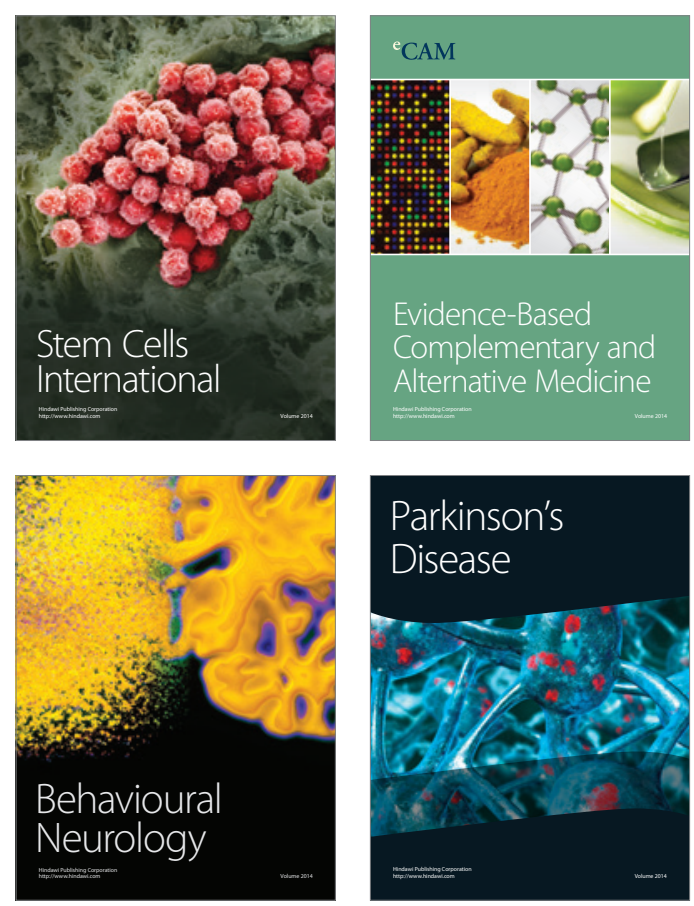

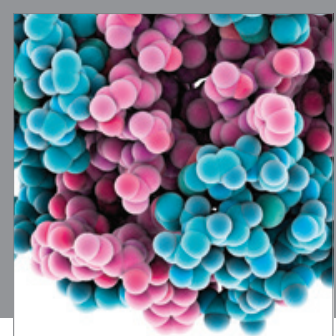

Journal of
Diabetes Research

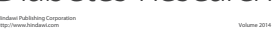

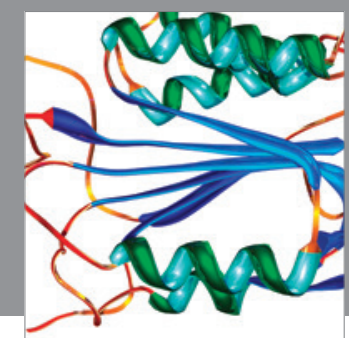

Disease Markers
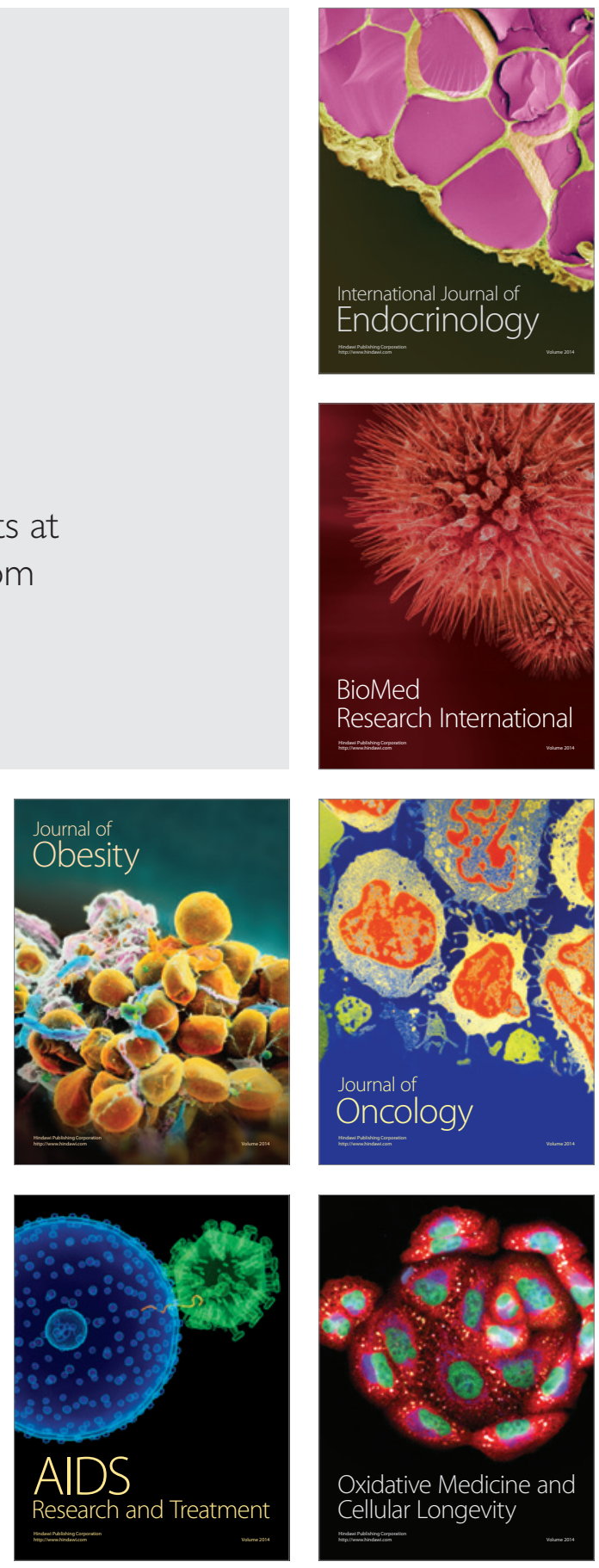